\title{
The Xanthomonas axonopodis pv. citri flagellum is required for mature biofilm and canker development
}

\author{
Correspondence \\ Adrián A. Vojnov \\ avojnov@fundacioncassara.org.ar
}

Received 3 August 2010

Revised 17 November 2010

Accepted 19 November 2010

\author{
Florencia Malamud, ${ }^{1}$ Pablo S. Torres, ${ }^{1}$ Roxana Roeschlin, ${ }^{2}$ \\ Luciano A. Rigano, ${ }^{1}$ Ramón Enrique, ${ }^{2}$ Hernán R. Bonomi, ${ }^{3}$ \\ Atilio P. Castagnaro, ${ }^{4}$ María Rosa Marano ${ }^{2}$ and Adrián A. Vojnov ${ }^{1}$ \\ ${ }^{1}$ Instituto de Ciencia y Tecnología Dr. Cesar Milstein, Fundación Pablo Cassará, CONICET, Saladillo \\ 2468 C1440FFX, Ciudad de Buenos Aires, Argentina \\ ${ }^{2}$ IBR - Depto. Microbiología, Facultad de Ciencias, Bioquímicas y Farmacéuticas, U.N.R. Suipacha \\ 531, S2002LRK, Rosario, Argentina \\ ${ }^{3}$ Fundación Instituto Leloir-CONICET, Av. Patricias Argentinas 435 C1405BWE, Buenos Aires, \\ Argentina \\ ${ }^{4}$ Estación Experimental Agroindustrial Obispo Colombres, Av. William Cross 3150, Las Talitas, \\ Tucumán, Argentina
}

\begin{abstract}
Xanthomonas axonopodis pv. citri $(\mathrm{Xac})$ is the causative agent of citrus canker. This bacterium develops a characteristic biofilm on both biotic and abiotic surfaces. To evaluate the participation of the single flagellum of $\mathrm{Xac}$ in biofilm formation, mutants in the fliC (flagellin) and the flgE (hook) genes were generated. Swimming motility, assessed on $0.25 \%$ agar plates, was markedly reduced in fliC and flgE mutants. However, the fliC and flgE mutants exhibited a flagellarindependent surface translocation on $0.5 \%$ agar plates. Mutation of either the rpfF or the rpfC gene, which both encode proteins involved in cell-cell signalling mediated by diffusible signal factor (DSF), led to a reduction in both flagellar-dependent and flagellar-independent surface translocation, indicating a regulatory role for DSF in both types of motility. Confocal laser scanning microscopy of biofilms produced in static culture demonstrated that the flagellum is also involved in the formation of mushroom-shaped structures and water channels, and in the dispersion of biofilms. The presence of the flagellum was required for mature biofilm development on lemon leaf surfaces. The absence of flagellin produced a slight reduction in Xac pathogenicity and this reduction was more severe when the complete flagellum structure was absent.
\end{abstract}

\section{INTRODUCTION}

Biofilms are bacterial communities in which cells are embedded in an extracellular polysaccharide (EPS) matrix that can be attached to a surface (Branda et al., 2005; Southey-Pillig et al., 2005). Life in these communities provides protection to the organisms from deleterious conditions (Davey \& O'Toole, 2000), and biofilm formation is considered to be important for the disease cycle of bacterial pathogens of both animals and plants. We are interested in understanding the role of biofilm formation in the development of canker disease by Xanthomonas axonopodis pv. citri (Xac), one of the most devastating

\footnotetext{
Abbreviations: CLSM, confocal laser scanning microscopy; CV, crystal violet; DSF, diffusible signal factor; EPS, extracellular polysaccharide; Xac, Xanthomonas axonopodis pv. citri; Xcc, Xanthomonas campestris pv. campestris.

Two supplementary figures are available with the online version of this paper.
}

diseases of citrus species. Xac is a foliar pathogen that enters the plant leaves through stomata and can infect both fruits and leaves (Brunings \& Gabriel, 2003). Confocal laser scanning microscopy (CLSM) of citrus cankers, using Xac bacteria expressing green fluorescent protein (GFP), showed the occurrence of structured arrangements of cells (Rigano et al., 2007b). Our aim here was to identify bacterial factors involved in the development of such threedimensional structures.

The development of bacterial biofilms is generally a multistep process, which is initiated when the bacteria reach a surface. First, the bacteria attach to a surface reversibly, where they can move freely across it until they become immobilized (Stoodley et al., 2002). To achieve a mature biofilm, new individuals appear in the community either by recruitment from planktonic bacteria or through replication of cells already present in the biofilm. Finally, some grouped cells disperse to develop new structures elsewhere (Heydorn et al., 2000; Tolker-Nielsen et al., 
2000). When the bacterial population reaches a certain density, the biofilm begins to mature through the production of an extracellular matrix which contributes greatly to the final architecture of the community (Branda et al., 2005).

Flagella have been implicated in surface attachment in several bacteria (Lemon et al., 2007; O’Toole \& Kolter, 1998a, b). For instance, flagella are necessary for swarming motility in Pseudomonas aeruginosa, which in turn is important in determining the final structure of the biofilm (Merritt et al., 2007). Similarly, Escherichia coli is not able to form an organized structure when flagella are lost. It has been proposed that E. coli flagella serve to overcome surface repulsion (Van Houdt \& Michiels, 2005) and also allow attached cells to migrate along the abiotic surface to facilitate biofilm expansion (Pratt \& Kolter, 1998). However, flagella are important but not essential for surface attachment in Vibrio cholerae El Tor (Watnick \& Kolter, 1999).

Previous work from our laboratory has established that synthesis of the EPS xanthan contributes to the formation of structured biofilms in Xac and that both synthesis of xanthan and cell-cell signalling involving diffusible signal factor (DSF) contribute to structured biofilm formation in the related Xanthomonas campestris pv. campestris (Xcc) (Rigano et al., 2007a; Torres et al., 2007). Synthesis and perception of DSF require proteins coded in the $r p f$ cluster (for regulation of pathogenicity factors). RpfF directs DSF synthesis whereas RpfC is involved in DSF perception (Barber et al., 1997; Slater et al., 2000). Mutants in the rpfF (DSF-minus) and $r p f C$ (DSF overproducer) genes in Xcc can only form unstructured arrangements of bacteria (Torres et al., 2007). Synthesis of xanthan is directed by genes from the gum operon (da Silva et al., 2002), which is highly conserved in Xanthomonas spp. Disruption of the first gene, gumB, leads to complete loss of xanthan production (Vojnov et al., 1998); strains of Xac or Xcc with mutations in gumB cannot form structured biofilms (Rigano et al., 2007b; Torres et al., 2007). Beyond DSF signalling and xanthan production, relatively little is known about factors influencing biofilm formation in Xanthomonas spp. and the role that the flagellum plays in this process.

Both $X c c$ and $X a c$ bear a single polar flagellum. Flagellar gene clusters encode all the structural proteins of the flagellum in Xac (da Silva et al., 2002). In addition, it has been shown that several genes encoding auxiliary protein subunits are involved in regulation of the flagellar assembly (Khater et al., 2007). As in many other bacterial species, FliC and FlgE proteins are the flagellin (Vonderviszt et al., 1998) and the hook components (Aizawa, 1996), respectively, of the flagellar structure. This structure is formed by a thin filament that protrudes from the cell body bound to a basal body that includes a rotor and a stator (Chevance \& Hughes, 2008).

Here we address the role of the single flagellum in biofilm formation in Xac. Our initial approach was to test the effects of mutations in fliC and flgE on motility and biofilm structure. Our results indicate that the flagellum and flagellum-dependent motility are important for initial adherence to surfaces, for the development of a mature structured biofilm and for biofilm dispersion. Unexpectedly, our observations reveal a second type of motility that is flagellum-independent and EPS-dependent. Both types of motility are regulated by the DSF signalling system. Thus, these findings indicate possible additional roles for cell-cell signalling and EPS in the biofilm formation process.

\section{METHODS}

Bacterial strains. Xanthomonas strains were cultured at $28{ }^{\circ} \mathrm{C}$ with shaking in PYM (Cadmus et al., 1976) or in Y minimal medium (YMM) (Sherwood, 1970). To examine biofilm development, bacteria were grown in YMM containing $1 \%(\mathrm{w} / \mathrm{v})$ glucose as the carbon source (Rigano et al., 2007b). E. coli was grown at $37{ }^{\circ} \mathrm{C}$ in Luria-Bertani medium (Sambrook et al., 1989). Bacterial growth was measured in a Spectronic 20 Genesys spectrophotometer (Thermo Electron) at $600 \mathrm{~nm}$. When required, the antibiotics ampicillin $\left(100 \mu \mathrm{g} \mathrm{ml}^{-1}\right)$, kanamycin $\left(50 \mu \mathrm{g} \mathrm{ml}^{-1}\right)$, spectinomycin $\left(100 \mu \mathrm{g} \mathrm{ml}^{-1}\right)$, tetracycline $\left(10 \mu \mathrm{g} \mathrm{ml}^{-1}\right)$ or gentamicin $\left(20 \mu \mathrm{g} \mathrm{ml}^{-1}\right)$ were added to the growth media.

Construction of fliC and flgE mutants. Molecular techniques and extraction of genomic DNA from Xac were performed according to Rigano et al. (2007b). To obtain the Xac $\Delta$ fliC mutant strain (fliC), the fliC gene was partially deleted. First, two fragments of 408 and $484 \mathrm{bp}$ were amplified from the region encoding the wild-type $\mathrm{Xac} f \mathrm{fiD}$ and $\mathrm{fliC}$ genes by using primers flic1/flic2 and flic3/flic4, respectively (Table 1). The fragments were digested with restriction enzyme XbaI, purified and ligated to one another. A PCR was then performed using this ligation as template and primers flicl/flic4. The PCR product was resolved by $0.8 \%$ agarose gel electrophoresis and a fragment of 892 bp was excised and purified from the gel using the Wizard SV Gel and PCR Clean-Up System (Promega). The product was cloned into pGEM-T easy (Promega) and subcloned into the suicide vector pk18mobsacB (Katzen et al., 1999), producing the $\mathrm{pK}-\Delta$ fliC construct.

The Xac flgE:: $\Omega$ strain (flgE) was constructed by allelic exchange. Two regions, upstream and downstream from flgE, were amplified using flge1/flge2 (546 bp) and flge3/flge4 (547 bp) primers, respectively (Table 1). The two fragments were digested with HindIII, purified and ligated to one another, and a PCR was then performed using this ligation as template and primers flgel/flge4. The PCR product of $1093 \mathrm{bp}$ was resolved and purified as described above. The product was cloned into pGEM-T easy and the $2 \mathrm{~kb} \mathrm{Sm}^{\mathrm{r}} / \mathrm{Spc}^{\mathrm{r}}$ cassette $(\Omega)$ was inserted in the HindIII restriction site. This construct was subcloned into pk18mobsacB, giving pK-flgE:: $\Omega$.

The two constructs, $\mathrm{pK}-\Delta f l i C$ and $\mathrm{pK}-f \lg E:: \Omega$, were used to transform the wild-type strain by electroporation (do Amaral et al., 2005). Transformed bacteria were selected on PYM agar medium supplemented with kanamycin (Müller et al., 1993). Sucrose-sensitive clones were grown in the absence of antibiotics and double recombination events were selected on PYM agar plates supplemented with $5 \%$ sucrose and spectinomycin in the case of the flgE mutant. $\mathrm{Km}^{\mathrm{s}} /$ sucrose $^{r}$ candidates were screened by PCR followed by sequencing of the amplified fragments. Isolated mutants were confirmed by flagellum staining as described by Kearns \& Losick (2003) and motility was further analysed.

For genetic complementation of the fliC mutant, the entire gene and $245 \mathrm{bp}$ from the upstream region were amplified by PCR using 
Table 1. Strains, plasmids and primers used in this study

\begin{tabular}{|c|c|c|}
\hline Strain, plasmid or primer & Relevant genotype or sequence $\left(5^{\prime}-3^{\prime}\right)$ & Source or reference \\
\hline \multicolumn{3}{|l|}{ Strains } \\
\hline$X a c$ & Wild-type, $A p^{r}$ & Rigano et al. (2007b) \\
\hline fliC & Xac $\Delta f l i c, \mathrm{Ap}^{\mathrm{r}}$ & This study \\
\hline$f \lg E$ & Xac flge: $: \Omega, \mathrm{Ap}^{\mathrm{r}} \mathrm{Sp}^{\mathrm{r}}$ & This study \\
\hline fliC-GFP & Xac $\Delta$ flic, $\mathrm{Ap}^{\mathrm{r}} \mathrm{Km}^{\mathrm{r}}$ & This study \\
\hline$c$-fliC & Xac $\Delta$ flic, $\mathrm{Ap}^{\mathrm{r}} \mathrm{Tc}^{\mathrm{r}}$ & This study \\
\hline$c-f l g E$ & Xac flge: $: \Omega, \mathrm{Ap}^{\mathrm{r}} \mathrm{Sp}^{\mathrm{r}} \mathrm{Tc}^{\mathrm{r}}$ & This study \\
\hline$r p f F$ & Xac $\Delta r p f F, \mathrm{Km}^{\mathrm{r}} \mathrm{Ap}^{\mathrm{r}}$ & Siciliano et al. (2006) \\
\hline$r p f C$ & $X a c \Delta r p f C, \mathrm{Km}^{\mathrm{r}} \mathrm{Ap}^{\mathrm{r}}$ & Siciliano et al. (2006) \\
\hline $\operatorname{gumB}$ & Xac $\Delta g u m b, \mathrm{Km}^{\mathrm{r}} \mathrm{Ap}^{\mathrm{r}}$ & Rigano et al. (2007b) \\
\hline E. coli $\mathrm{DH} 5 \alpha$ & hsdR recA lacZYA $\phi 80$ lacZ $\Delta \mathrm{M} 15$ & Gibco-BRL \\
\hline pLAFR 3 & $\mathrm{Tc}^{\mathrm{r}}$ & Staskawicz et al. (1987) \\
\hline $\mathrm{pK}-\Delta f l i C$ & $\mathrm{Km}^{\mathrm{r}}$ & This study \\
\hline pK-flgE:: $\Omega$ & $\mathrm{Km}^{\mathrm{r}} \mathrm{Sp}^{\mathrm{r}}$ & This study \\
\hline pLAFR-fliC & $\mathrm{Tc}^{\mathrm{r}}$ & This study \\
\hline pLAFR-flgE & $\mathrm{Tc}^{\mathrm{r}}$ & This study \\
\hline \multicolumn{3}{|l|}{ Primers } \\
\hline Flic1 & GCGAATTCGCCTTGTTGATGCGTGCCTG $\dagger$ & This study \\
\hline Flic2 & GCTCTAGATTCCGCAGAACGTGCTGAGC $\ddagger$ & This study \\
\hline Flic3 & GCTCTAGAGAGATACCGTCGTTGGCGTT & This study \\
\hline Flic4 & 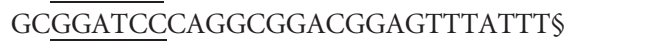 & This study \\
\hline Flge1 & GGGAATCGCAAAAGCGGGAT & This study \\
\hline RT-flic antisense & TGAACGCTCAGCGGAACCTCA & This study \\
\hline RT-gumb sense & AAACACGATGACATTGCCGC & This study \\
\hline RT-gumb antisense & GCCATATTTCGTTGCCGCTC & This study \\
\hline RT-16S sense & TGGTAGTCCACGCCCTAAACG & This study \\
\hline RT-16S antisense & CTGGAAAGTTCCGTGGATGTC & This study \\
\hline
\end{tabular}

${ }^{\star} \mathrm{Km}^{\mathrm{r}}, \mathrm{Ap}^{\mathrm{r}}, \mathrm{Gm}^{\mathrm{r}}, \mathrm{Sp}^{\mathrm{r}}$ and $\mathrm{Tc}^{\mathrm{r}}$ indicate kanamycin, ampicillin, gentamicin, spectinomycin and tetracycline resistance, respectively. Sites for restriction enzymes are underlined: $† E c o R I, \ddagger X b a \mathrm{I}, \S B a m H I$, $\|$ HindIII.

primers c-Flic-sense and Flic4 (Table 1). The amplified fragment was cloned into pLAFR3 (Staskawicz et al., 1987) to obtain pLAFR-fliC. Similarly, the flgE gene was amplified using primers c-Flge-sense and c-Flge-antisense (Table 1); the amplicon was cloned into pLAFR3 to obtain pLAFR-flgE. Both constructs were confirmed by DNA sequencing and electroporated into fliC and flgE mutant strains.

Bacterial adhesion and biofilm quantification. The crystal violet (CV) technique was used to quantify biofilm development of the different strains on an abiotic surface (O'Toole \& Kolter, 1998b). Bacterial strains were grown overnight in PYM nutrient medium and then inoculated into YMM to a final $\mathrm{OD}_{600}$ of 0.1 . Aliquots of $150 \mu \mathrm{l}$ were used to fill the wells of a 96-well polystyrene plate and incubated at $28{ }^{\circ} \mathrm{C}$ for 24,48 or $72 \mathrm{~h}$. To confirm similar bacterial growth, the $\mathrm{OD}_{600}$ was measured before the adhesion assay was performed.

To analyse the capacity of the strains to adhere to the abiotic surface, bacteria from an overnight culture growth in YMM at $28{ }^{\circ} \mathrm{C}$ and 200 r.p.m. were used. Aliquots of $150 \mu$ were dispensed into the wells of a 96-well plate and bacteria were incubated as previously described for 1, 3, 6 and $24 \mathrm{~h}$. The $\mathrm{OD}_{600}$ and cell attachment were measured as described above.

For quantification of biofilm development and adhesion of cells to an abiotic surface, the medium was gently removed using a pipette, and the 96-well plate was washed using $0.9 \% \mathrm{NaCl}$ and stained with $0.1 \%$ $\mathrm{CV}$ solution. After $30 \mathrm{~min}$ incubation the unbound $\mathrm{CV}$ stain was 
removed and the wells were washed with distilled water. The CV in each well was solubilized by adding $150 \mu \mathrm{l} 70 \%$ ethanol and was quantified by absorbance at $570 \mathrm{~nm}$.

The adhesion value was normalized according to the number of cells. This value was termed relative adhesion $\left(A_{570} / \mathrm{OD}_{600}\right)$.

In vitro and in vivo analysis of biofilm by CLSM. For in vitro experiments each strain expressing the autofluorescent protein GFP was grown at $28{ }^{\circ} \mathrm{C}$ on PYM supplemented with kanamycin. The $\mathrm{OD}_{600}$ was adjusted to 0.004 in YMM. Aliquots of $500 \mu \mathrm{l}$ were transferred to chambered coverglass slides containing a $1 \mu \mathrm{m}$ thick borosilicate glass (no. 155411; Lab-Tek, Nunc), as described by Russo et al. (2006).

Biofilm formation was monitored with a Zeiss LSM 510/Axiovert $100 \mathrm{M}$ confocal laser scanning microscope at 1, 2, 3, 4 and 5 days postinoculation (days p.i.) of the bacteria on the chambered coverglass slides. The assay was performed in triplicate and three-dimensional images were generated by the program Zeiss LSM Image Browser, version 3.2.0.

For in vivo studies, leaves of lemon (Citrus limon) were infected by spraying with a $1 \times 10^{6}$ c.f.u. $\mathrm{ml}^{-1}$ suspension of GFP-labelled wildtype $\mathrm{Xac}$ or the $\mathrm{fliC}$ or $\mathrm{flgE}$ mutants. After 6 days of incubation, areas of approximately $1 \mathrm{~cm}^{2}$ were cut from the leaves and mounted on the adaxial leaf surface under glass coverslips. The samples were observed with a Nikon C1 confocal laser scanning microscope. The simulated images obtained were analysed with the program Nikon EZ-C1. Assays were performed in triplicate.

Quantification of biofilm structures. Quantifications of biofilm volume and thickness of three-dimensional CLSM biofilm image stacks were performed by using the COMSTAT program (Heydorn et al., 2000). For comparative analysis of the wild-type, fliC and flgE mutant strains, three independent biofilm experiments were performed. In each round, seven image stacks were acquired at the following time points: $1,2,3,4$ and 5 days p.i.

RNA purification and RT-PCR. Total RNA of Xac cells was isolated by using an RBC kit, according to the manufacturer's instructions (RBCBioscience). The RNA was treated with RNase-free DNase (Promega) and the integrity of the nucleic acid was checked by agarose gel electrophoresis. Total RNA $(1 \mu \mathrm{g})$ was used to synthesize the cDNA using MMLV-RT (Promega) and the oligonucleotide dN6. Expression of the gumB, fliC and $16 \mathrm{~S}$ genes was determined by RTPCR using the primers listed in Table 1.

The density corresponding to the RT-PCR bands was quantified by using ImageJ 1.41 software from the National Institutes of Health (http://rsbweb.nih.gov/ij/download.html). Each gene was normalized using $16 \mathrm{~S}$ rRNA as the housekeeping gene. The ratio between normalized $f l i C$ or $g u m B$ in $r p f C$ and $r p f F$ mutants and in wild-type $X a c$ was determined. Data are expressed as the mean $\pm \operatorname{SEM}(n=3)$.

Motility assays. Motility assays were performed as described by Rashid \& Kornberg (2000). Briefly, bacteria were grown overnight in PYM medium, then $3 \mu \mathrm{l}$ of bacterial cultures with normalized $\mathrm{OD}_{600}$ were used to inoculate plates of $0.25 \%$ agar NYGB medium (Barber et al., 1997) (swimming) and 0.5\% agar PYM. After $72 \mathrm{~h}$, motility was assessed qualitatively by examining the circular halo formed by the growing bacterial cells. The assays were performed in triplicate.

Flagellar staining with CV. Flagellar staining was done based on a modification of the method described by Mayfield \& Inniss (1977). The staining solution was prepared by mixing 10 vols solution A ( $2 \mathrm{~g}$ tannic acid, $10 \mathrm{ml} 5 \%$ phenol, $10 \mathrm{ml} \mathrm{AlKO} \mathrm{S}_{2} \cdot 12 \mathrm{H}_{2} \mathrm{O}$ ) with 1 vol. $12 \%(\mathrm{w} / \mathrm{v}) \mathrm{CV}$ in ethanol. Then $3 \mu \mathrm{l}$ of bacterial culture grown overnight in PYM $\left(\mathrm{OD}_{600} 2\right)$ was placed over a coverglass with a coverslip and $10 \mu \mathrm{l}$ of the solution was used. Observations were made with an optical microscope (Carl Zeiss). (a)

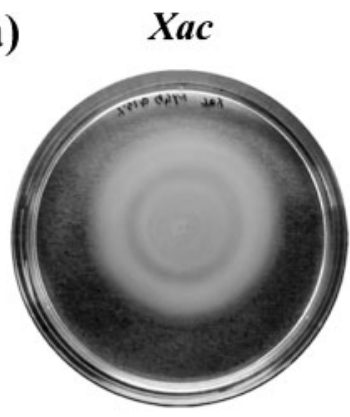

(b)

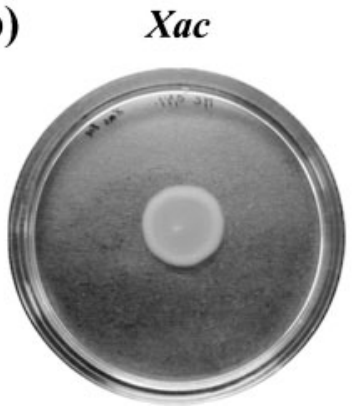

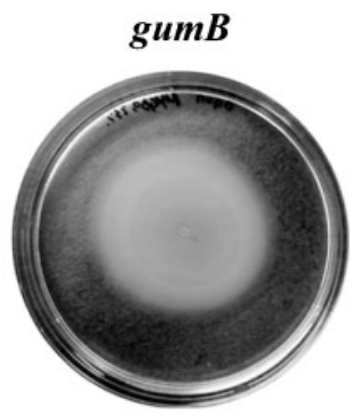
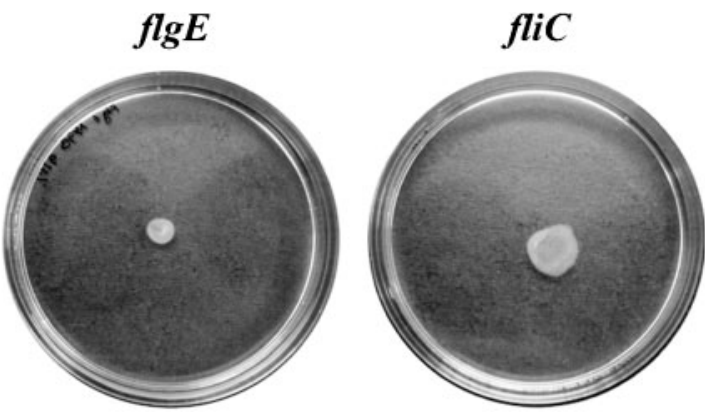

$\operatorname{gumB}$
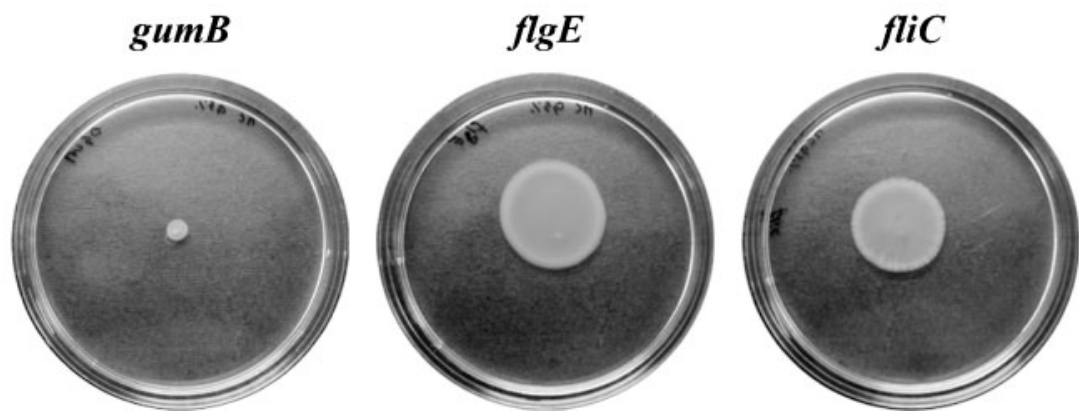

Fig. 1. Effects of mutation of the fliC, flgE and gumB genes on motility in Xac. (a) Flagellum-dependent swimming motility on $0.25 \%$ NYGB agar plates. (b) Motility on $0.5 \%$ PYM agar plates with $1 \%$ glucose. 
Plant material and inoculations. Citrus limon 'Eureka' was used as the host plant for Xac. Plants were kept in a controlled temperature room at $20-25{ }^{\circ} \mathrm{C}$ and with a $16 \mathrm{~h}$ photoperiod. Bacteria were grown in PYM with the appropriate antibiotics. Bacterial suspensions were diluted in $10 \mathrm{mM} \mathrm{MgCl}_{2}$ to a final concentration of $1 \times 10^{4}, 1 \times 10^{5}$ or $1 \times 10^{6}$ c.f.u. $\mathrm{ml}^{-1}$ and were inoculated by spraying as previously described (Rigano et al., 2007b). Bacterial growth in the host plant was quantified as previously described (Rigano et al., 2007b), using $1 \times 10^{6}$ c.f.u. $\mathrm{ml}^{-1}$ to spray the leaves. Statistical significance of differences between bacterial populations was determined by Student's unpaired two-tailed $t$-test. $P$-values $<0.05$ were considered statistically relevant. Cankers from 20 inoculated leaves were quantified and their areas were calculated using the program ImageJ version 1.41 .

\section{RESULTS}

\section{FliC and FlgE are required for swimming motility}

The genomic arrangement near the fliC and flgE genes in $X a c$ is shown in Supplementary Fig. S1(a), available with the online version of this paper. Xac strains with either a fliC deletion or a disruption in the flgE gene with a spectinomycin resistance cassette were created as described in Methods (Supplementary Fig. S1b). The mutations were confirmed by PCR (Supplementary Fig. S1c) and DNA sequence analysis (data not shown). The absence of the flagellar structure in these mutants was confirmed by CV staining (Kearns \& Losick, 2003). A typical single polar flagellum was observed in wild-type Xac, but was absent in the two mutants (Supplementary Fig. S1d). This observation confirms the expected and fundamental role for FliC and $\mathrm{FlgE}$ in the morphogenesis of the flagellum in Xac.

The ability of the different Xac strains to swim in lowpercentage agar was assayed to evaluate the role of the flagellum in motility. NYGB $0.25 \%$ agar plates were inoculated with the wild-type strain and the fliC and flgE mutants. After incubation at $28{ }^{\circ} \mathrm{C}$ for $72 \mathrm{~h}$, both mutants showed a considerable reduction in their motility compared with the wild-type (Fig. 1a). This was expected because the same phenotype has been reported for these kinds of mutations in other bacteria (Murray \& Kazmierczak, 2006; Young et al., 1999). The complemented mutant strains showed a partial restoration of their motility, confirming that no other genes had been affected in the mutants (Supplementary Fig. S2). (a)
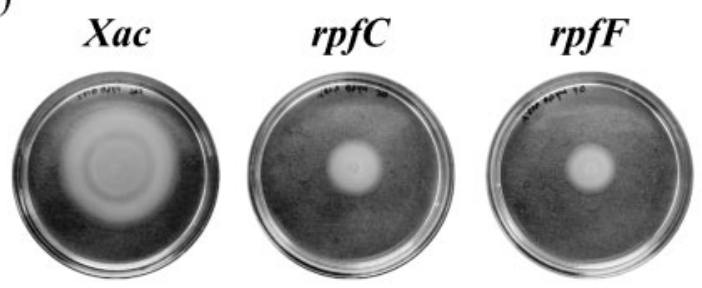

(b)
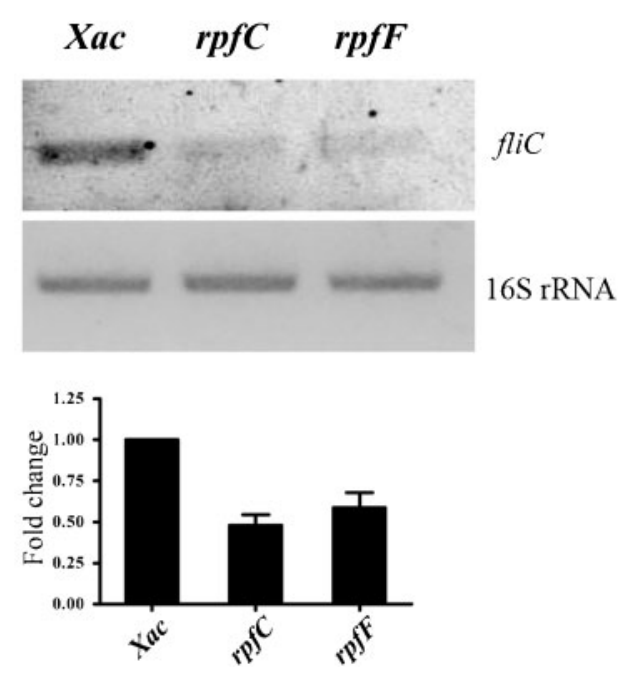

(c)

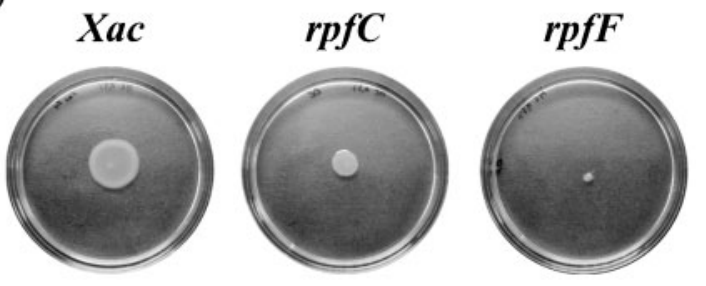

(d)
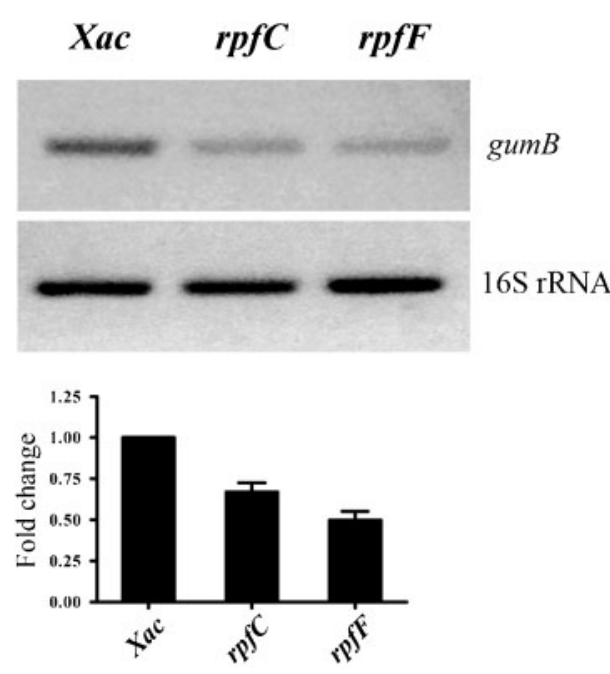

Fig. 2. Motility and gene expression in Xac strains with disruptions in the Rpf/DSF signalling system. (a) Flagellum-dependent swimming motility on $0.25 \%$ agar NYGB plates. (b) Expression of the fliC gene assessed by semi-quantitative RT-PCR using cDNA from wild-type Xac, and $r p f C$ and $r p f F$ mutants grown in YMM medium to stationary phase $(n=3)$. (c) Motility on $0.5 \%$ PYM agar plates with $1 \%$ glucose. (d) Expression of the gumB gene assessed by semi-quantitative RT-PCR in wild-type Xac, and $r p f C$ and $r p f F$ mutants grown in YMM medium to stationary phase $(n=3)$. 


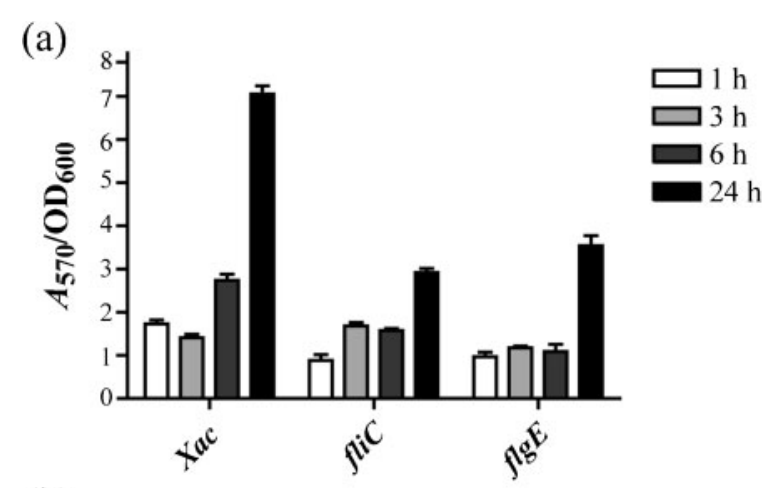

(b)

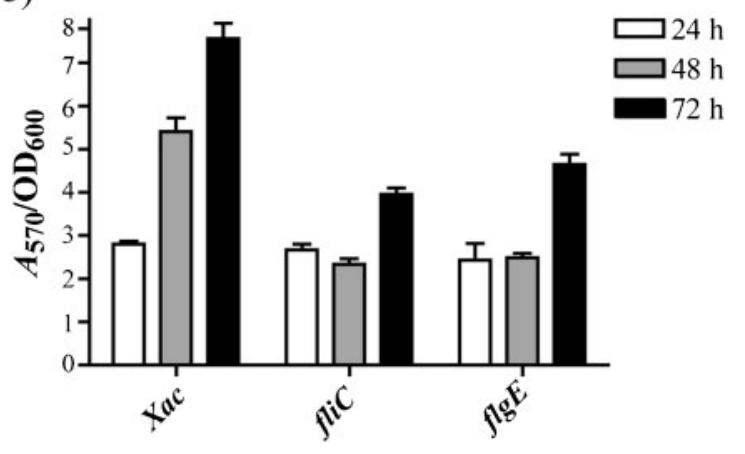

Fig. 3. Adhesion and biofilm development of Xac strains in vitro. (a) Adhesion in a 96-well polystyrene plate. Aliquots $(150 \mu \mathrm{l})$ of overnight cultures were used to inoculate the plates. $\mathrm{OD}_{600}$ measurements and crystal violet (CV) assays were performed at 1 , 3, 6 and $24 \mathrm{~h}$ after inoculation. (b) Biofilm development on wells of a 96-well polystyrene plate. Overnight cultures in nutrient medium were diluted in YMM to final $\mathrm{OD}_{600}$ of 0.1 . The $\mathrm{OD}_{600}$ measurements and CV assays were performed at 24, 48 and $72 \mathrm{~h}$ after inoculation. Three independent experiments with six replicates for each strain were performed. Error bars represent SEM.

In Xcc, DSF signalling elevates the expression of a wide range of genes, including those involved in flagellum synthesis (He et al., 2006). This prompted us to evaluate whether DSF signalling regulates swimming motility in $X a c$. The reduced motility of $r p f F$ and $r p f C$ mutants (Fig. 2a) and the reduced expression levels of $\mathrm{fliC}$ in both mutants (Fig. 2b) were indicative that flagellar-mediated swimming in Xac depends on cell-cell signalling. The gumB mutant showed a wild-type motility, indicating that xanthan has no role in Xac swimming motility (Fig. 1a). The gumB gene, as reported previously (Vojnov et al., 2001), is also regulated by the DSF/Rpf system (Fig. 2d).

\section{A second type of Xac motility is independent of the flagellum}

The different Xac strains were also tested for motility on $0.5 \%$ agar PYM swarm plates. Both fliC and flgE mutants showed a comparable surface translocation to the wild-type (Fig. 1b) although the gumB (Fig. 1b) and $r p f$ (Fig. 2c)
Fig. 4 (on facing page). Structural analysis of biofilms formed by Xac strains by CLSM. GFP-tagged cells were grown for 5 days in chambered cover slides and observed daily. (a) Panels (left to right) show the projection in the $x-y$ plane at 3,4 and 5 days p.i. for Xac wild-type, and fliC and flgE mutants. Magnification, $\times 1000$. Bars, $10 \mu \mathrm{m}$. Arrows indicate some of the aggregates. (b) Mean thickness of the biofilm structure at different days after inoculation calculated by the COMSTAT program. Error bars represent SEM. (c) Biovolume of the biofilm structure at different days after inoculation calculated by the COMSTAT program. Error bars represent SEM. (d) Biofilm structures on day 5 after inoculation: projection in the $x-y$ plane with a magnification of $\times 1000$ and a twofold digital amplification. (e) Biofilm structures at 5 days p.i.: projection in the $x-z$ plane with a magnification of $\times 1000$ and a twofold digital amplification. Bars, $5 \mu \mathrm{m}$. Arrows indicate groups of pioneer cells. Three independent experiments were carried out for each strain with essentially the same outcome.

mutants showed a reduction in motility. Given these findings, under the conditions here, motility was not dependent on the presence of a flagellum, but was dependent on xanthan production and DSF signalling. Such motility has been termed 'sliding' (Horng et al., 2002), and it has been proposed that EPS acts as a surfactant or surfacewetting agent to facilitate this type of movement (Murray \& Kazmierczak, 2008).

\section{Flagellar mutants show reduced attachment to abiotic surfaces and biofilm development}

Adhesion to an abiotic surface and biofilm formation was assayed using 96-well polystyrene plates and CV staining. The fliC and flgE mutants showed reduced adherence throughout a $24 \mathrm{~h}$ experiment, suggesting that the intact flagellum is required for this stage (Fig. 3a). To follow biofilm development, a lower bacterial concentration $\left(\mathrm{OD}_{600} 0.1\right)$ was used to inoculate the 96-well plates. Staining of the biofilm was performed at 24, 48 and $72 \mathrm{~h}$. The wild-type Xac showed an increased biofilm biomass as revealed by $\mathrm{CV}$ staining while the biofilm biomass of the $f l i C$ and $f l g E$ mutants was reduced. However, these strains were still able to attach and develop a biofilm at $72 \mathrm{~h}$ (Fig. 3b).

\section{Role of the flagellum in the structural development of Xac biofilms}

We previously observed by CLSM that GFP-tagged Xanthomonas strains develop three-dimensional biofilm structures in static cultures in minimal medium, by using chambered cover slides (Rigano et al., 2007b; Torres et al., 2007). During the initial attachment Xac first contacted the glass surface in a polar fashion before becoming attached laterally. The colony of attached bacteria then spread over the entire well (Fig. 4a, day 3 and data not shown). After this first step, Xac developed microcolonies that increased in number (Fig. 4a). A more structured biofilm was formed from these microcolonies after 4 days (Fig. 4a). At higher 
(a)

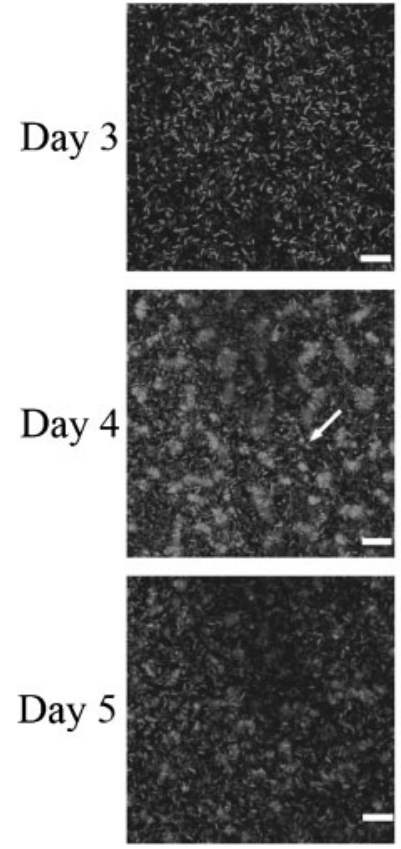

Xac
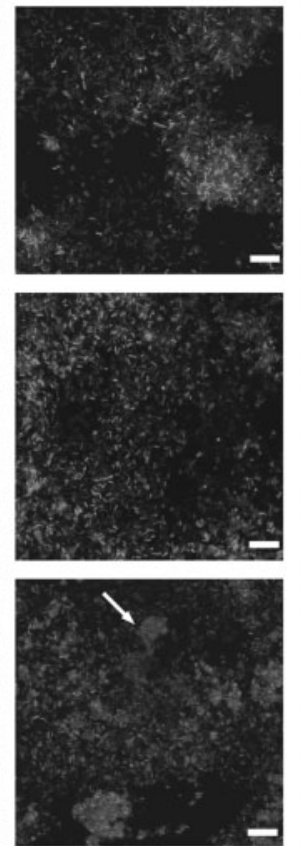

fliC (b)
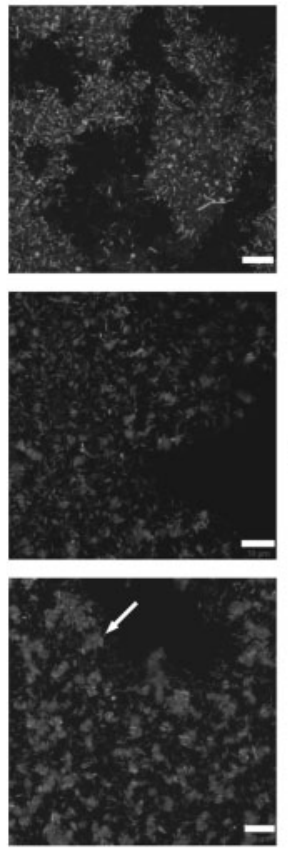

flgE

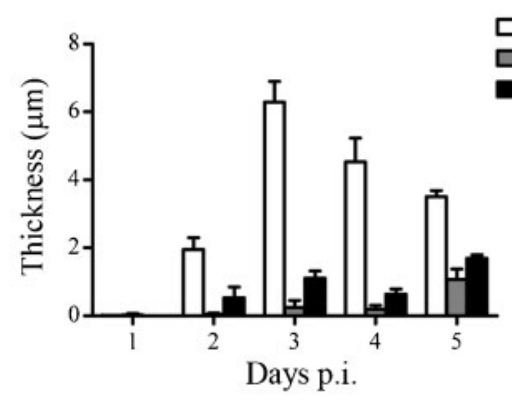

(c)

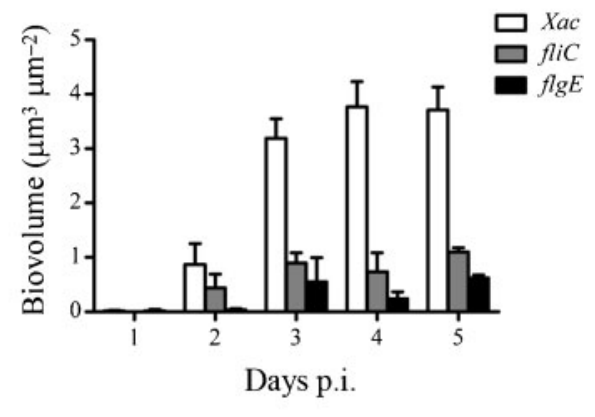

(d)

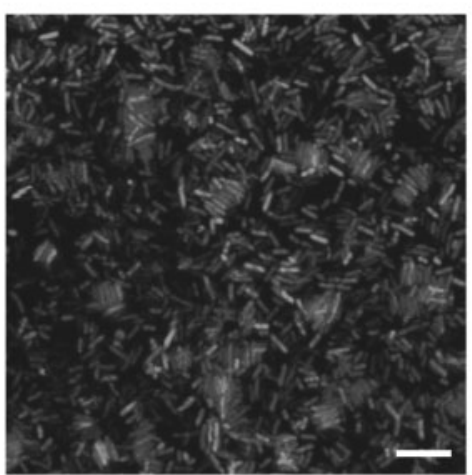

Xac

(e)

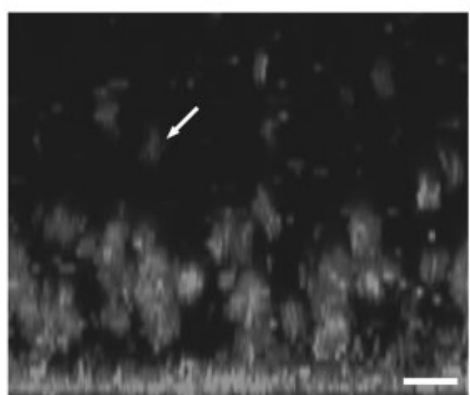

$X a c$

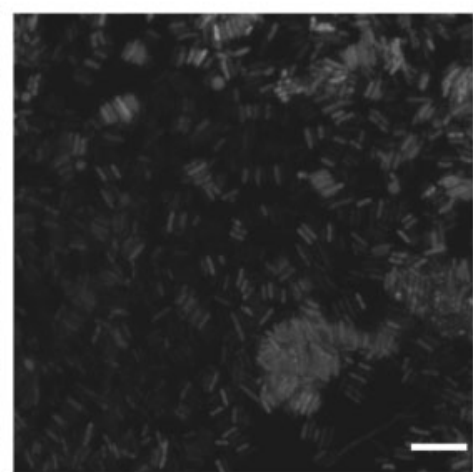

fliC

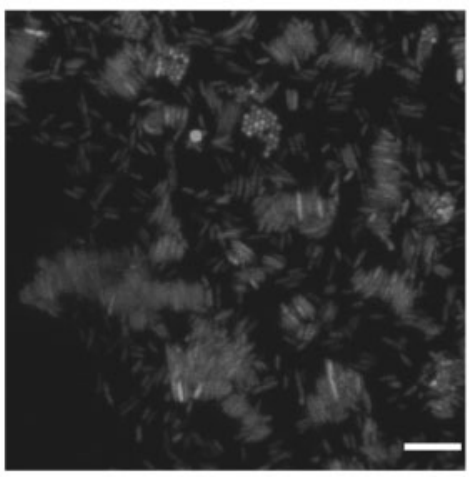

flgE

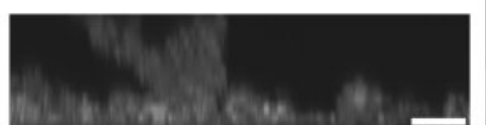

fliC

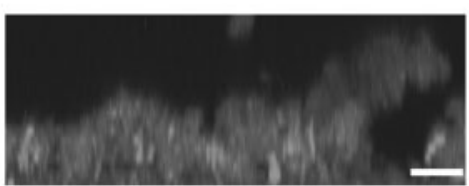

flgE magnifications, it was possible to observe that the bacteria were linked predominantly through lateral interactions. After 5 days, wild-type Xac developed mushroom-type structures separated by extensive water channels (Fig. 4e). At this time, some groups of cells (pioneer cells) spread from the biofilm to other locations (Fig. 4e). 

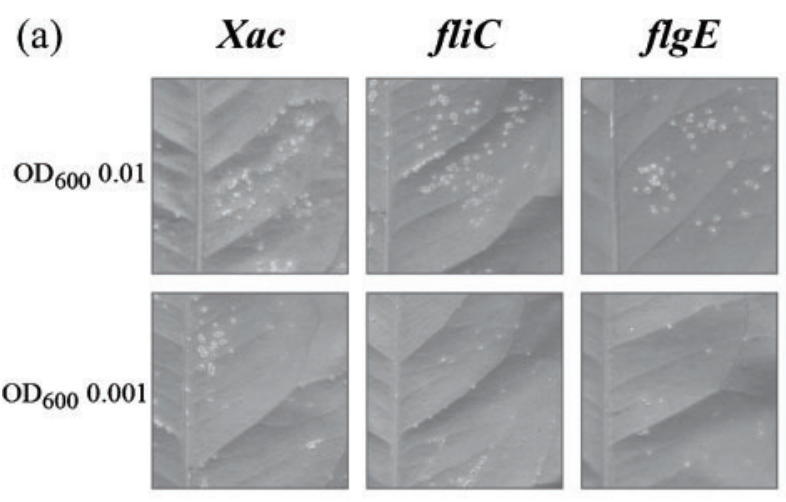

(b)

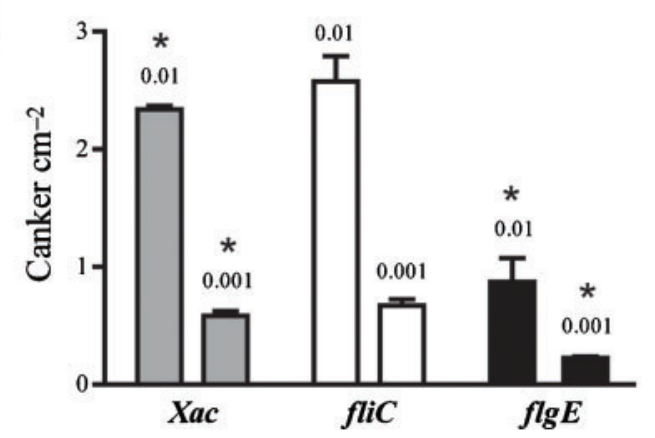

(c)

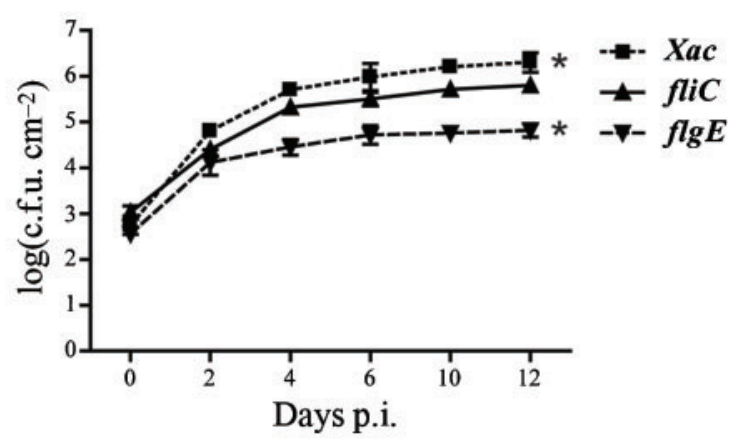

(d)

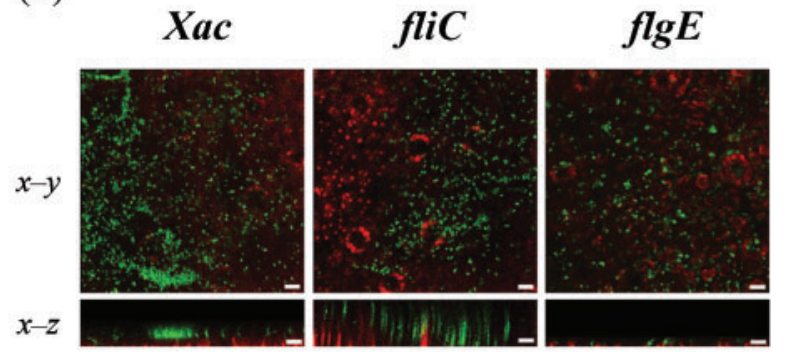

Fig. 5. Canker development, bacterial growth and biofilm formation on the surface of leaves infected with Xac strains by the spray method. (a) Lemon leaves at 22 days p.i. with $1 \times 10^{5}$ or $1 \times 10^{4}$ c.f.u. $\mathrm{ml}^{-1}$. (b) Quantification of canker lesions in lemon leaves at 22 days p.i. Twenty leaves were assayed and the results are the means of four independent experiments \pm SD. The $\mathrm{OD}_{600}$ of the suspensions used for inoculation is indicated above the bars. Asterisks indicate a statistically significant difference between the flgE mutant and the wild-type at both concentrations of bacterial suspension. (c) Growth in vivo of Xac strains on C. limon leaves infected with $1 \times 10^{6}$ c.f.u. $\mathrm{ml}^{-1}$. Values are means of three independent experiments \pm SD. Datasets marked with an asterisk are significantly different according to the two-tailed Student's $t$-test $(P<0.05)$. (d) Biofilm structure analysis at 6 days p.i. using CLSM and GFP-labelled cells at a concentration of $1 \times 10^{6}$ c.f.u. $\mathrm{ml}^{-1}$. The panels show projections in the $x-y$ and $x-z$ planes with a magnification of $\times 100$. Red indicates chlorophyll autofluorescence. Three independent experiments were assayed with essentially the same outcome.

Although the fliC and flgE mutants showed no apparent alteration in the first steps of cell attachment, they were not able to occupy the whole surface area of the chamber, in contrast to the wild-type strain (Fig. 4a, d). After 3 days, both mutants were able to develop aggregates (Fig. 4a, day 4) that later formed structures similar to those of the wildtype but thinner (Fig. 4d). Furthermore, these mutants failed to form a mature biofilm (Fig. 4e). These visual observations were confirmed by quantification of two variables, mean thickness and biofilm volume, by using the COMSTAT program (Fig. 4b, c).

\section{The flagellum is involved in mature biofilm formation on leaf surfaces and is required for bacterial growth and canker development}

To investigate if the flagellar mutants were affected in virulence, canker development, bacterial growth and biofilm formation, we evaluated the mutant strains in the lemon leaves infection model. The plants were sprayinoculated with $\mathrm{Xac}$ wild-type, fliC and flgE mutant strains. Fig. 5(a) shows canker symptoms on lemon leaves 22 days p.i. at a concentration of $1 \times 10^{4}$ and $1 \times 10^{5}$ c.f.u. $\mathrm{ml}^{-1}$. Quantification of canker lesions in lemon leaves was done at 22 days p.i. The flgE mutant was severely compromised in its ability to cause canker disease in citrus leaves (Fig. $5 b)$. Comparison of bacterial numbers in planta revealed no significant statistical difference between Xac wild-type and the fliC mutant. However, the flgE mutant showed a statistically significant reduction in growth compared with the Xac wild-type (Fig. 5c).

When biofilm was analysed at 6 days p.i. on lemon leaves, the wild-type strain showed aggregation within a typical biofilm, as observed previously (Rigano et al., 2007b) (Fig. 5d). However, biofilms from the $\mathrm{fliC}$ and $f \operatorname{lgE}$ mutants developed in a more dispersed fashion with either few or no aggregated structures. The flgE mutant was more affected than the fliC mutant (Fig. 5d). 


\section{DISCUSSION}

In the present study we have addressed the importance of motility and the role of the flagellum in the development of mature biofilm structures in Xac. Previous work from our group showed that a wild-type Xac strain was able to attach and develop a biofilm with an organized structure on both abiotic and biotic surfaces. Similar structures were also seen within the cankers of infected plants (Rigano et al., 2007b). In addition, it has been shown that the xanthan polysaccharide in $\mathrm{Xac}$ is essential in the formation of microcolonies and the subsequent development of more complex structures (Rigano et al., 2007b). In the present work, we show evidence that the flagellum is essential for the establishment of a mature biofilm in Xac, that EPS is required for a flagellum-independent type of motility ('sliding') and that both sliding motility and swimming motility (flagellum-dependent) are regulated by the rpfl DSF system.

In addition to swimming motility in low-percentage agar media, many bacteria exhibit swarming motility on plates with higher $(0.5-0.6 \%, \mathrm{w} / \mathrm{v})$ agar concentrations. Swarming motility is associated with changes in flagella number and/or placement, quorum sensing, and also with the production of wetting agents (Henrichsen, 1972; Kaiser, 2007; Overhage et al., 2007). Both flagella and type IV pili contribute to swarming in Pseudomonas aeruginosa (Harshey, 1994; Rashid \& Kornberg, 2000) and probably in other bacteria (Köhler et al., 2000; Overhage et al., 2007). In contrast, Xac is capable of flagellum-independent surface translocation on $0.5 \%$ agar PYM. We consider that this type of motility is more consistent with sliding rather than swarming. Sliding motility has been defined as 'a kind of translocation produced by expansive forces in a growing culture in combination with special surface properties of the cells resulting in reduced friction between cell and substrate' (Murray \& Kazmierczak, 2008). Unlike swarming, sliding motility does not require flagella (Henrichsen, 1972). It is not known how DSF signalling and EPS impinge on the proposed sliding motility, although it is possible that EPS plays a role in modifying the properties of the agar surface to promote motility.

Xac does not exhibit twitching motility (unpublished observations), and consequently it is tempting to speculate that the type of motility described here as sliding has a role in the formation of initial microcolonies which occurs in a flagellum-independent manner. This remains an open question however, since the factors that we demonstrate to influence sliding are DSF signalling, which has a very pleiotropic effect in Xanthomonas spp., and the EPS xanthan, which probably also has a number of different roles in biofilm formation (Dow et al., 2003).

Bacterial attachment, the formation of aggregates or microcolonies, and finally biofilm maturation have been recognized as the three stages of biofilm development that are responsive to diverse environmental signals (Stanley \& Lazazzera, 2004). Mutations of the $f l i C$ or flgE gene significantly reduced, but did not eliminate, initial attachment to both abiotic and biotic surfaces, suggesting that other genes may be involved in this process. CLSM revealed that in chambered slides, fliC and flgE mutants do not develop the structured organization seen in wild-type Xac. A typical biofilm contains bacteria tightly packed in hexagonal arrays separated by water-filled channels that allow nutrient flux between the towers of cells, and develops multicellular mushroom-shaped structures. The biofilms of the flagellar mutants lack water channels, which may explain why these mutants produce thinner structures that are reflected in the low CV staining. Overall, the data suggest that the flagellum plays a major role in the formation of the mature Xac biofilm. However, it remains unclear whether this deficiency is due to the absence of the flagellum structure or the absence of motility.

Similarly to the findings described here, a study in Xcc reported that the absence of flagellin affected the swimming motility of the bacteria as expected but did not alter virulence (Lee et al., 2003). However, results obtained with other vascular pathogens such as Ralstonia solanacearum, Pantoea stewartii and Dickeya dadantii showed that the flagellum-dependent motility was required for biofilm formation and systemic colonization of the host plant (Herrera et al., 2008; Jahn et al., 2008; Tans-Kersten et al., 2001). Although the mutation in the $\mathrm{fliC}$ gene in Xac affects the formation of biofilm structures, these strains are not significantly less virulent. The mutation in the $f l g E$ gene, in contrast, affects both the ability to form biofilms and virulence. As far as we are aware, this is the first study to establish the participation of FlgE in biofilm formation and virulence in a Xanthomonas species.

\section{ACKNOWLEDGEMENTS}

This work was supported by the Agencia de Promoción Científica y Tecnológica (ANPCyT) and the Consejo Nacional de Investigaciones Científicas y Técnicas (CONICET). A. P. C., M. R. M. and A. A. V. are members of CONICET. F. M., P. S. T., L. A. R., H. R. B. and R. E. were supported by a CONICET fellowship. We thank Angeles Zorreguieta and J. Maxwell Dow for critically reading the manuscript. We are grateful to Tomás Santa Coloma for making the confocal (Zeiss) microscope available. We thank S. Scarpeci for helping with the confocal microscopy and Ms Carlota Thompson for her advice and careful revision of the English text.

\section{REFERENCES}

Aizawa, S. I. (1996). Flagellar assembly in Salmonella typhimurium. Mol Microbiol 19, 1-5.

Barber, C. E., Tang, J. L., Feng, J. X., Pan, M. Q., Wilson, T. J., Slater, H., Dow, J. M., Williams, P. \& Daniels, M. J. (1997). A novel regulatory system required for pathogenicity of Xanthomonas campestris is mediated by a small diffusible signal molecule. Mol Microbiol 24, 555-566.

Branda, S. S., Vik, S., Friedman, L. \& Kolter, R. (2005). Biofilms: the matrix revisited. Trends Microbiol 13, 20-26. 
Brunings, A. M. \& Gabriel, D. W. (2003). Xanthomonas citri: breaking the surface. Mol Plant Pathol 4, 141-157.

Cadmus, M. C., Rogovin, S. P., Burton, K. A., Pittsley, J. E., Knutson, C. A. \& Jeanes, A. (1976). Colonial variation in Xanthomonas campestris NRRL B-1459 and characterization of the polysaccharide from a variant strain. Can J Microbiol 22, 942-948.

Chevance, F. F. \& Hughes, K. T. (2008). Coordinating assembly of a bacterial macromolecular machine. Nat Rev Microbiol 6, 455-465.

da Silva, A. C., Ferro, J. A., Reinach, F. C., Farah, C. S., Furlan, L. R., Quaggio, R. B., Monteiro-Vitorello, C. B., Van Sluys, M. A., Almeida, N. F. \& other authors (2002). Comparison of the genomes of two Xanthomonas pathogens with differing host specificities. Nature 417, 459-463.

Davey, M. E. \& O'Toole, G. A. (2000). Microbial biofilms: from ecology to molecular genetics. Microbiol Mol Biol Rev 64, 847-867.

do Amaral, A. M., Toledo, C. P., Baptista, J. C. \& Machado, M. A. (2005). Transformation of Xanthomonas axonopodis pv. citri by electroporation. Fitopatol Bras 30, 292-294.

Dow, J. M., Crossman, L., Findlay, K., He, Y. Q., Feng, J. X. \& Tang, J. L. (2003). Biofilm dispersal in Xanthomonas campestris is controlled by cell-cell signaling and is required for full virulence to plants. Proc Natl Acad Sci U S A 100, 10995-11000.

Harshey, R. M. (1994). Bees aren't the only ones: swarming in gramnegative bacteria. Mol Microbiol 13, 389-394.

He, Y. W., Xu, M., Lin, K., Ng, Y. J., Wen, C. M., Wang, L. H., Liu, Z. D., Zhang, H. B., Dong, Y. H. \& other authors (2006). Genome scale analysis of diffusible signal factor regulon in Xanthomonas campestris pv. campestris: identification of novel cell-cell communicationdependent genes and functions. Mol Microbiol 59, 610-622.

Henrichsen, J. (1972). Bacterial surface translocation: a survey and a classification. Bacteriol Rev 36, 478-503.

Herrera, C. M., Koutsoudis, M. D., Wang, X. \& von Bodman, S. B. (2008). Pantoea stewartii subsp. stewartii exhibits surface motility, which is a critical aspect of Stewart's wilt disease development on maize. Mol Plant-Microbe Interact 21, 1359-1370.

Heydorn, A., Nielsen, A. T., Hentzer, M., Sternberg, C., Givskov, M., Ersboll, B. K. \& Molin, S. (2000). Quantification of biofilm structures by the novel computer program COMSTAT. Microbiology 146, 23952407.

Horng, Y. T., Deng, S. C., Daykin, M., Soo, P. C., Wei, J. R., Luh, K. T., Ho, S. W., Swift, S., Lai, H. C. \& Williams, P. (2002). The LuxR family protein SpnR functions as a negative regulator of $\mathrm{N}$-acylhomoserine lactone-dependent quorum sensing in Serratia marcescens. Mol Microbiol 45, 1655-1671.

Jahn, C. E., Willis, D. K. \& Charkowski, A. O. (2008). The flagellar sigma factor fliA is required for Dickeya dadantii virulence. Mol PlantMicrobe Interact 21, 1431-1442.

Kaiser, D. (2007). Bacterial swarming: a re-examination of cellmovement patterns. Curr Biol 17, R561-R570.

Katzen, F., Becker, A., lelmini, M. V., Oddo, C. G. \& lelpi, L. (1999). New mobilizable vectors suitable for gene replacement in gramnegative bacteria and their use in mapping of the $3^{\prime}$ end of the Xanthomonas campestris pv. campestris gum operon. Appl Environ Microbiol 65, 278-282.

Kearns, D. B. \& Losick, R. (2003). Swarming motility in undomesticated Bacillus subtilis. Mol Microbiol 49, 581-590.

Khater, L., Alegria, M. C., Borin, P. F., Santos, T. M., Docena, C., Tasic, L., Farah, C. S. \& Ramos, C. H. (2007). Identification of the flagellar chaperone FlgN in the phytopathogen Xanthomonas axonopodis pathovar citri by its interaction with hook-associated FlgK. Arch Microbiol 188, 243-250.
Köhler, T., Curty, L. K., Barja, F., van Delden, C. \& Pechere, J. C. (2000). Swarming of Pseudomonas aeruginosa is dependent on cell-tocell signaling and requires flagella and pili. J Bacteriol 182, 59905996.

Lee, M. C., Weng, S. F. \& Tseng, Y. H. (2003). Flagellin gene $f l i C$ of Xanthomonas campestris is upregulated by transcription factor Clp. Biochem Biophys Res Commun 307, 647-652.

Lemon, K. P., Higgins, D. E. \& Kolter, R. (2007). Flagellar motility is critical for Listeria monocytogenes biofilm formation. J Bacteriol 189, 4418-4424.

Mayfield, C. I. \& Inniss, W. E. (1977). A rapid, simple method for staining bacterial flagella. Can J Microbiol 23, 1311-1313.

Merritt, P. M., Danhorn, T. \& Fuqua, C. (2007). Motility and chemotaxis in Agrobacterium tumefaciens surface attachment and biofilm formation. J Bacteriol 189, 8005-8014.

Müller, P., Keller, M., Weng, W. M., Quandt, J., Arnold, W. \& Puhler, A. (1993). Genetic analysis of the Rhizobium meliloti exoYFQ operon: ExoY is homologous to sugar transferases and ExoQ represents a transmembrane protein. Mol Plant-Microbe Interact 6, 55-65.

Murray, T. S. \& Kazmierczak, B. I. (2006). FlhF is required for swimming and swarming in Pseudomonas aeruginosa. J Bacteriol 188, 6995-7004.

Murray, T. S. \& Kazmierczak, B. I. (2008). Pseudomonas aeruginosa exhibits sliding motility in the absence of type IV pili and flagella. J Bacteriol 190, 2700-2708.

O'Toole, G. A. \& Kolter, R. (1998a). Flagellar and twitching motility are necessary for Pseudomonas aeruginosa biofilm development. Mol Microbiol 30, 295-304.

O'Toole, G. A. \& Kolter, R. (1998b). Initiation of biofilm formation in Pseudomonas fluorescens WCS365 proceeds via multiple, convergent signalling pathways: a genetic analysis. Mol Microbiol 28, 449461.

Overhage, J., Lewenza, S., Marr, A. K. \& Hancock, R. E. (2007). Identification of genes involved in swarming motility using a Pseudomonas aeruginosa PAO1 mini-Tn5-lux mutant library. J Bacteriol 189, 2164-2169.

Pratt, L. A. \& Kolter, R. (1998). Genetic analysis of Escherichia coli biofilm formation: roles of flagella, motility, chemotaxis and type I pili. Mol Microbiol 30, 285-293.

Rashid, M. H. \& Kornberg, A. (2000). Inorganic polyphosphate is needed for swimming, swarming, and twitching motilities of Pseudomonas aeruginosa. Proc Natl Acad Sci U S A 97, 4885-4890.

Rigano, L. A., Payette, C., Brouillard, G., Marano, M. R., Abramowicz, L., Torres, P. S., Yun, M., Castagnaro, A. P., Oirdi, M. E. \& other authors (2007a). Bacterial cyclic beta-(1,2)-glucan acts in systemic suppression of plant immune responses. Plant Cell 19, 2077-2089.

Rigano, L. A., Siciliano, F., Enrique, R., Sendín, L., Filippone, P., Torres, P. S., Qüesta, J., Dow, J. M., Castagnaro, A. P. \& other authors (2007b). Biofilm formation, epiphytic fitness, and canker development in Xanthomonas axonopodis pv. citri. Mol Plant-Microbe Interact 20, 1222-1230.

Russo, D. M., Williams, A., Edwards, A., Posadas, D. M., Finnie, C., Dankert, M., Downie, J. A. \& Zorreguieta, A. (2006). Proteins exported via the PrsD-PrsE type I secretion system and the acidic exopolysaccharide are involved in biofilm formation by Rhizobium leguminosarum. J Bacteriol 188, 4474-4486.

Sambrook, J., Fritsch, E. \& Maniatis, T. (1989). Molecular Cloning: A Laboratory Manual. Cold Spring Harbor, NY: Cold Spring Harbor Laboratory.

Sherwood, M. T. (1970). Improved synthetic medium for the growth of Rhizobium. J Appl Bacteriol 33, 708-713. 
Siciliano, F., Torres, P. S., Sendin, L., Bermejo, C., Filippone, P., Vellice, G., Ramallo, J., Castagnaro, A., Vojnov, A. \& Marano, M. R. (2006). Analysis of the molecular basis of Xanthomonas axonopodis pv. citri pathogenesis in Citrus limon. Electron J Biotechnol 9, 200204.

Slater, H., Alvarez-Morales, A., Barber, C. E., Daniels, M. J. \& Dow, J. M. (2000). A two-component system involving an HD-GYP domain protein links cell-cell signalling to pathogenicity gene expression in Xanthomonas campestris. Mol Microbiol 38, 986-1003.

Southey-Pillig, C. J., Davies, D. G. \& Sauer, K. (2005). Characterization of temporal protein production in Pseudomonas aeruginosa biofilms. J Bacteriol 187, 8114-8126.

Stanley, N. R. \& Lazazzera, B. A. (2004). Environmental signals and regulatory pathways that influence biofilm formation. Mol Microbiol 52, 917-924.

Staskawicz, B., Dahlbeck, D., Keen, N. \& Napoli, C. (1987). Molecular characterization of cloned avirulence genes from race 0 and race 1 of Pseudomonas syringae pv. glycinea. J Bacteriol 169, 5789-5794.

Stoodley, P., Sauer, K., Davies, D. G. \& Costerton, J. W. (2002). Biofilms as complex differentiated communities. Annu Rev Microbiol 56, 187-209.

Tans-Kersten, J., Huang, H. \& Allen, C. (2001). Ralstonia solanacearum needs motility for invasive virulence on tomato. J Bacteriol 183, 3597-3605.

Tolker-Nielsen, T., Brinch, U. C., Ragas, P. C., Andersen, J. B., Jacobsen, C. S. \& Molin, S. (2000). Development and dynamics of Pseudomonas sp. biofilms. J Bacteriol 182, 6482-6489.
Torres, P. S., Malamud, F., Rigano, L. A., Russo, D. M., Marano, M. R., Castagnaro, A. P., Zorreguieta, A., Bouarab, K., Dow, J. M. \& Vojnov, A. A. (2007). Controlled synthesis of the DSF cell-cell signal is required for biofilm formation and virulence in Xanthomonas campestris. Environ Microbiol 9, 2101-2109.

Van Houdt, R. \& Michiels, C. W. (2005). Role of bacterial cell surface structures in Escherichia coli biofilm formation. Res Microbiol 156, 626-633.

Vojnov, A. A., Zorreguieta, A., Dow, J. M., Daniels, M. J. \& Dankert, M. A. (1998). Evidence for a role for the gumB and gumC gene products in the formation of xanthan from its pentasaccharide repeating unit by Xanthomonas campestris. Microbiology 144, 14871493.

Vojnov, A. A., Slater, H., Daniels, M. J. \& Dow, J. M. (2001). Expression of the gum operon directing xanthan biosynthesis in Xanthomonas campestris and its regulation in planta. Mol Plant-Microbe Interact 14, 768-774.

Vonderviszt, F., Imada, K., Furukawa, Y., Uedaira, H., Taniguchi, H. \& Namba, K. (1998). Mechanism of self-association and filament capping by flagellar HAP2. J Mol Biol 284, 1399-1416.

Watnick, P. I. \& Kolter, R. (1999). Steps in the development of a Vibrio cholerae El Tor biofilm. Mol Microbiol 34, 586-595.

Young, G. M., Smith, M. J., Minnich, S. A. \& Miller, V. L. (1999). The Yersinia enterocolitica motility master regulatory operon, flhDC, is required for flagellin production, swimming motility, and swarming motility. J Bacteriol 181, 2823-2833.

Edited by: I. K. Toth 